\begin{tabular}{|l|l|l||}
\hline \multicolumn{2}{|c|}{ PublisherInfo } \\
\hline \hline PublisherName & $:$ & BioMed Central \\
\hline \hline PublisherLocation & $:$ & London \\
\hline \hline PublisherImprintName & $:$ & BioMed Central \\
\hline \hline
\end{tabular}

\title{
Francis Crick dies
}

\begin{tabular}{|l|c|l||}
\hline \multicolumn{2}{|c|}{ ArticleInfo } \\
\hline \hline ArticleID & $:$ & 4986 \\
\hline \hline ArticleDOI & $:$ & $10.1186 /$ gb-spotlight-20040730-01 \\
\hline \hline ArticleCitationID & $:$ & spotlight-20040730-01 \\
\hline \hline ArticleSequenceNumber & $:$ & 49 \\
\hline \hline ArticleCategory & $:$ & Research news \\
\hline ArticleFirstPage & $:$ & 1 \\
\hline \hline ArticleLastPage & $:$ & 5 \\
\hline \hline & & RegistrationDate : 2004-7-30 \\
\hline ArticleHistory & $:$ & OnlineDate \\
\hline \hline ArticleCopyright & $:$ & BioMed Central Ltd2004-7-30 \\
\hline \hline ArticleGrants & $:$ & \\
\hline \hline ArticleContext & $:$ & 130595511 \\
\hline \hline
\end{tabular}


Francis Crick, known for his discovery with James Watson of the double helix but described by a biologist colleague as "the absolute master in a way that nobody else in that generation was," died in San Diego, California. He was 88.

"If all you think of with Francis Crick is the double helix, then you don't know the man," Crick's Cambridge contemporary and Nobel prize winner Aaron Klug told us. Although Crick did perform many of the intellectual somersaults that revealed DNA's double helix - work for which he shared the 1962 Nobel Prize in Physiology or Medicine - that was only one of the world-changing discoveries that littered his career, according to Klug. While many of his achievements are now so established that they are the stuff of the school curriculum, in their time each was the pinnacle of scientific achievement.

Born on June 8, 1916 in Northampton, UK, Francis Harry Compton Crick in 1937 got a degree in physics at University College London, before spending World War II devising ways of sweeping German magnetic mines for the British Admiralty, and designing circuits for British magnetic and acoustic mines. During the war he also married Ruth Dodd, and the couple had a son, Michael.

Around the time that the war ended, so too did his marriage. In 1947 he married Odile Speed, and the couple had two daughters, Gabrielle and Jacqueline. 1947 also marked a significant change in his working life, as Crick moved to Strangeways Laboratory, Cambridge, where he studied the physical properties of cytoplasm in cultured fibroblast cells, a task he found intellectually limiting.

"He always knew who to go and talk to about problems," recalled Cambridge physiologist Horace Barlow. "He sought me out because he knew that I was interested in neuroscience. He was already working on a problem in cell biology, but he didn't think it was very important - all he wanted to do was get that finished with. He wondered whether to go into neurosciences."

After much thought, Crick headed for what is now called molecular biology. "He took his choice and he was obviously right. He could have persuaded me to go into molecular biology, but I was such a bad chemist," Barlow said. So, in 1949 Crick joined the Medical Research Council research group in Cambridge. He wanted to bring science to the mysteries at the border between living and non-living. The team was led by Max Perutz, and Crick worked on protein structure, ending up doing a PhD on Xray diffraction of proteins.

In 1951 James Watson arrived in Cambridge fresh from receiving his $\mathrm{PhD}$ at Indiana University in Bloomington, and the two instantly joined forces. Crick once said that their collaboration worked largely because they were never afraid to rigorously question each other's ideas, and the result was their Nature paper on April 25, 1953 that revealed the structure of DNA.

In 1957 Crick became excited about the Central Dogma, his theory that DNA passed its information to RNA, and this was then used to generate specific proteins. "Watson had something similar in his notebook, but Crick went around preaching it as certainty," said Richard Henderson, who first met Crick when he joined the Cambridge team as a PhD student in 1966. Then came the 'adapter hypothesis,' in which Crick realized that small molecules were involved in translating the RNA code-sequence into amino acids. These adapters turned out to be tRNA. 
In 1958 he published a paper with his student David Blow in which they showed how to determine the structure of proteins using heavy atom derivatives. "The method dominated the field for decades," said Henderson, and Crick's 1959 election as a Fellow of the Royal Society confirmed his status in the field.

Crick began studying structure and function of histones in 1960. At the time, he thought that histones held the two chains of DNA apart for transcription. "That was wrong," Klug said, "but what Crick realized was that the 25 different histones were post-synthetic variants of four (it turned out to be 5) major types of histones."

The triplet codon became his next target, in 1966. Working with Sydney Brenner, Crick determined that each amino acid in a protein related to three bases in the genetic code. "That is the most beautiful elegant paper," Klug said.

Crick then came up with the wobble hypothesis. This theorized that while the first two bases in a triplet were always stringently complemented during tRNA's binding with mRNA, the third one was often less critically followed - there was an element of 'wobble' in the way that the code was translated into protein.

With thirty years of experience in molecular biology, and some 87 papers bearing his name, Crick made a radical shift in 1977. A long-standing colleague, Leslie Orgel, persuaded him to move to the Salk Institute in la Jolla, California, where he started studying neurobiology. "I thought he was the most brilliant guy, and it would be intellectually stimulating for all of us to have him around," Orgel told us.

With Graeme Mitchison, he investigated dreams, suggesting they were mechanisms for clearing out the debris of unwanted experience. With Orgel, he toyed with Panspermia - the theory that life developed on a far away planet and arrived on earth aboard a spaceship. But it was his interest in determining the neuronal correlates of consciousness that was his main passion over the following three decades. "He had a big influence in the Salk in building up their neuroscience program. It is now probably the foremost centre in the States, if not the world," Henderson said.

"When he started his work on consciousness, this was something no neuroscientist wanted to touch, it was not respectable," said Tomaso Poggio, professor of vision sciences and biophysics at MIT. "Now he has managed to make it work, to ask scientific questions about it to encourage others to do experiments on it. So, I think it has been an important contribution."

Starting in 1984, Crick started working extensively with neuroscientist Christof Koch, and together they co-authored most of Crick's papers associated with neuroscience. "Our theory was that consciousness involves specific neurons, firing in a specific way and sitting in a specific part of the brain," Koch told us. Their work focused on the visual system, and their working hypothesis is that while the primary visual cortex is important for vision, it does not generate ultimate conscious perception - in other words, the correlates are not in the primary visual cortex.

Back in Cambridge his absence was noted - particularly in seminars where he gained a reputation for grilling presenters. "He gave no quarter," said Klug. "He subjected you to criticism and expected you to stand up, though he was fairly kindly to young people. He didn't suffer fools kindly - that sums him up."

Crick's scientific method was rigorous. According to Klug, he learned it from the professor in charge of the Cambridge laboratory when Crick first arrived. He learnt sift though vast mounds of information 
and identify the reliable data. "He could reduce it to its essence" said Klug. "Then he was in a position to design experiments to test it, or else look for pieces of evidence from other people's work."

"Crick said to me in the early 70s that it difficult to imagine a problem that would not be solved in 25 years," said Michael Levitt of Stanford University, California. For Crick, he said, the trick was correctly formulating the question. For example, in 1998 he wrote a paper with Koch in which he sets out his rational for tackling the issue of consciousness. He begins by defining a few critical questions, at the same time as listing areas that are not worth approaching, because science is not ready to formulate questions.

"He was intellectually penetrating and rational, in a way that has been more successful than anyone else," Orgel said. This enabled him frequently to be decades ahead of the game. "He worked out the coilcoil structure of proteins before he sorted out DNA, but no one took much notice of it until a few years ago when it was shown to be quite correct - I thought that was really fun."

\section{References}

1. Francis Crick, [http://www.salk.edu/faculty/crick.html]

2. Aaron Klug, [http://www.nobel.se/chemistry/laureates/1982/klug-autobio.html]

3. Francis Crick 1962 Nobel biography, [http://www.nobel.se/medicine/laureates/1962/crick-bio.html]

4. Max Perutz, [http://www.nobel.se/chemistry/laureates/1962/perutz-bio.html]

5. James Watson Nobel biography, [http://www.nobel.se/medicine/laureates/1962/watson-bio.html]

6. Crick comments, [http://www.mnsu.edu/emuseum/information/biography/abcde/crick_francis.html]

7. Henderson homepage, [http://www2.mrc-lmb.cam.ac.uk/research/SS/Henderson_R/

Henderson_R.html]

8. Sydney Brenner Nobel biography, [http:/www.nobel.se/medicine/laureates/2002/brennerautobio.html]

9. Leslie Orgel, [http://www.salk.edu/faculty/orgel.html] 
10. Tomaso Poggio homepage, [http://web.mit.edu/mcgovern/html/Principal_Investigators/ poggio.shtml]

11. Christof Koch, [http://www.klab.caltech.edu/ koch/]

12. Michael Levitt, [http://csb.stanford.edu/levitt/]

13. Crick/Koch 1998 paper, [http://www.klab.caltech.edu/ koch/crick-koch-cc-97.html] 